\title{
THE RESPONSIBILITY OF ENGAGING IN CONTEMPORARY THEOLOGY: A FEW OBSERVATIONS
}

\author{
Ernst M Conradie \\ Department of Religion and Theology \\ University of the Western Cape
}

\begin{abstract}
This paper is born from recognition of the responsibility of engaging in "contemporary theology", that is, the task of articulating and reflecting on the question "Who is God and what is God doing today, in my life, in my family, in this Christian community, in this local context, in this country, continent and world?" Theologians, realising the complexity of the question, may prefer to shy away from it. However, that would leave room for others to answer the question in rather simplistic and often fundamentalist ways. The paper offers some rather bold observations as a stimulus to engage in contemporary theology in South Africa in a responsible way. The argument is structured in the following sections: 1. A brief overview of some challenges and threats facing Christianity in South Africa. 2. A critical analysis of various ways of responding to these challenges. 3. The need to resist religious reductionism and to dare to speak about God. 4. Some broad parameters within which contemporary Christian witnesses to God's love may be tested.
\end{abstract}

\section{Introduction}

This contribution is born out of a recognition of the responsibility of engaging in what I would like to call "contemporary theology", that is, the task of reflecting on the very basic theological questions "Who is God?" and "What is God doing today, in my life, in my family, in this Christian community, in this local context, in this country, this continent and in the world?" Indeed, what is the message that God has for us today? Or, in the famous formulation of Dietrich Bonhoeffer, Who is Jesus Christ, for us, today?

There are several reasons why theologians may want to shy away from such questions. At best, this may be born from the humble recognition that we can all too easily talk about God in an idle way, that in our talk about God we can seek to define and to control God, to create God according to our own image and to what we would like God to be. Or we may want to acknowledge that living a life in the presence of God is more important than articulate God-talk. It may also result from a realisation of the enormous hermeneutical complexity of such questions. ${ }^{1}$ All too often superficial answers are given to such questions. Such easy answers are often provided in fundamentalist discourse but also among those who, in an attempt to "read the signs of the time," regard it as their duty to provide a running theological commentary on the events of the day.

Nevertheless, the willingness to address such questions should be appreciated. To shy away from such questions may be self-destructive. Theological discourse may focus on the church, various forms of spirituality, church doctrine, the Bible, Biblical hermeneutics, the

1. In several earlier contributions on theological hermeneutics I have discussed the complexity of the task of doing theology (see Conradie 1990, 1993, Conradie and Jonker 2001). In this contribution I will make a more constructive contribution towards a contemporary theology. 
history of Christianity, congregational management, the finances of the church, social issues (poverty, injustice, rape, various forms of violence, HIV/AIDS, the environment), human religious experience, the lives of saints, the work of famous theologians, etc. without ever addressing the questions that contemporary theology has to raise. It is debatable whether such theological discourse may strictly speaking be called theological, i.e. talking about (and to!) a living God. Moreover, that would leave room for others to answer the question in rather simplistic and often fundamentalist ways. This contribution will offer some rather bold observations as a stimulus to engage in contemporary theology in South Africa in a responsible way.

\section{Challenges and Threats posed to Contemporary Theology}

Any contemporary theology needs to be relevant within and for a particular context and time. Relevance, of course, may easily become a misleading slogan. Any form of social analysis will necessarily be extremely complex and controversial. Instead of engaging in such an exercise of social analysis, I will here simply remind us of a number of important contextual challenges that any contemporary theology in South Africa will have to address. I will focus on challenges that may at the same time be considered as threats to Christian theology. They are not only challenges that Christian theology may help to address. They are challenges that call Christian theology into question, at times radically. To address such challenges may therefore also offer Christian theology an opportunity for renewal and transformation.

Robert Wuthnow, an influential American sociologist identifies the following list of challenges that Christianity (not only in America) will have to face in the $21^{\text {st }}$ century: institutional, ethical, socio-political, doctrinal, and cultural challenges. ${ }^{2}$ I will use his analysis as a point of departure (adding some ideological and religious challenges) in order to investigate some of the challenges of our times.

\section{a) Institutional Challenges}

Community life is usually structured around healthy social institutions (schools, sports clubs, business corporations, labour unions, church groups, community organisations). While institutions may sometimes become static and rigid, they do provide a certain stability without which society will become severely fragmented. ${ }^{3}$ They help to structure and to maintain community life.

The processes of industrialisation and urbanisation have led to the fragmentation of community life. The need for a sense of "belonging" has, not surprisingly, come to be identified as one of the primary functions that religious institutions can fill. This certainly applies to the South African context as well. The significant title of Inus Daneel's important study on African Instituted Churches is Quest for belonging. ${ }^{4}$ The question is indeed whether Christianity can respond to this challenge in a pluralistic (ethnic, social, religious) and divided society? Can it offer warm caring communities, a sense of belonging?

2. Wuthnow (1993).

3. On the challenges that social fragmentation pose to Christianity, see the classic study by Robert Bellah (1985) and Rasmussen (1993). See also Rasmussen's plea for a retrieval of sustainable community (Rasmussen 1996, Wellman 2001)

4. Daneel (1987). 
b) Ethical challenges

Christianity is not only about beliefs or experiences. It also concerns the ways in which we live. Many challenges emerge in this area. In the past, Christianity has often been criticised for instigating or condoning military crusades, witch hunts, the rise of capitalism, colonialism, the subjugation of women and ecological destruction. Furthermore, the views of Christian churches on numerous specific ethical questions (e.g. abortion, the death penalty, economic justice, birth control, divorce, violence against women, gay and lesbian rights, HIV/AIDS, etc.) have often been criticised. At the same time, it has become difficult to determine what churches should do in a (postmodern) world where straightforward rules for deciding how to live have fallen into question. In such a context, churches will have to reflect on moral formation, on appropriate ways of nurturing ethical behaviour and cultivating habits of moral reasoning. How Christians will respond to these ethical challenges will clearly determine the credibility of Christian communities.

It is important to note that there are some ethical issues where not only the credibility, but also the very identity of the church is at stake. These are ethical issues that provoke far more penetrating theological questions. These include the following:

- The status of women in society: Christianity has often been accused of instigating and maintaining patriarchal structures and thought patterns in society. Christian theology can ill afford to ignore questions about the perceived maleness of Christian God-talk.

- Christian complicity in ecological devastation: In a famous, if controversial, essay Lynn White argued that Christianity bears a "huge burden of guilt" for the ecological crisis. ${ }^{5}$ This can hardly be denied. At the same time, ecological discourse has questioned several dominant themes in Christian theology, including the preoccupation with a radically transcendent (deist) notion of God, a dualist anthropology, a personalist soteriology and an escapist, otherworldly eschatology. ${ }^{6}$

- Gay and lesbian rights: Debates on gay and lesbian issues have proved to be extremely divisive for Christian communities. This is understandable since such debates pose fundamental questions regarding a Christian understanding of human sexuality, marriage and family life.

- Suffering: The immense human suffering related to poverty, the HIV-AIDS pandemic, genocide and political oppression that has become so endemic to our world continues to raise the theodicy question rather starkly: Why does a God of love allow so much suffering to continue unabated?

\section{c) Doctrinal Challenges}

Many Christian beliefs are contested inside and outside the Christian tradition. Some prefer to evade issues of doctrine altogether because these are perceived to be divisive. Others prefer to focus on personal religious experiences and resist an overly intellectual form of faith. Some prefer to articulate the content of Christian faith purely in terms of narratives, songs or proverbs, instead of systematic arguments. However, there is often a lack of clarity about basic terms such as doctrine, truth, faith and belief. Questions concerning the Bible, revelation, Christian truth claims and issues of doctrine remain disconcerting for many Christians. Furthermore, doctrinal and denominational differences are, contrary to what some may assume, not a thing of the past, also not on the African continent. They can be

5. See White (1967)

6. For one response to these doctrinal challenges, see my Hope for the earth (Conradie 2000). 
divisive and continue to shape people's sense of identity. Conceptual clarity on issues of doctrine therefore remains crucial.

\section{d) Socio-political Challenges}

There is a wide range of socio-political issues on the social agenda of Christianity. In Africa these clearly include issues such as civil war, anarchy, poverty, famine, unemployment, international debt, domestic violence, the plight of women and children, education, environmental destruction, and HIV/AIDS. Christians respond in different ways to these social challenges. Some Christian communities prefer to focus on purely religious matters. In these contexts Christianity becomes a privatised religion, unable to speak to a pluralistic society beyond the confines of a narrowly defined community. Others prefer to address these issues without any reference to religion. Few manage to relate their religious convictions to public life in such a way that they make a contribution to the general public without compromising the integrity of their religious convictions.

\section{e) Cultural Challenges}

Cultural, ethnic and religious diversity poses an important challenge to Christianity. In the past, such diversity was confined to distinct geographic regions. In a context of globalisation and urbanisation, contact (and often conflict) between people from different cultural backgrounds is inevitable. In contexts of cultural diversity questions about personal and communal identity become increasingly significant. Who am I? To which community do I belong? How can I cope with "walking in two worlds?" How am I different from people of other cultures? How do I cope with changing circumstances, with a culture in flux? Is it appropriate for me to derive my identity from the mass media, from a culture of consumerism? It is pertinent to note that such cultural diversity is present within our own sense of identity. We do not only live in a context of cultural diversity; we find a sense of cultural diversity within ourselves.

In South Africa, these cultural challenges have become particularly imperative, especially with respect to the relationship between Christian identity and African identity. All too often the Christianity that has taken root in South Africa has been and still is dominated by altogether European theologies, debates, spiritualities, forms of ministry, church leadership and expressions of worship. Subsequently, there has been a widespread call in South Africa for "Christianity with an African face". These observations beg numerous further theological questions regarding the relationship between Christianity and culture. In the ongoing debates on this relationship, several key concepts have been introduced and discussed. These include the notions of "indigenisation", "contextuallisation", inculturalisation", "accommodation", or simply "Africanisation". "Each of these concepts remains disputed though. The relationship between Christianity and (African) culture continues to call for further clarification.

\section{f) Ideological Challenges: Secularisation, Globalisation and Consumerism}

Many social analysts have observed that the secularisation thesis that was popular in the 1960's could not predict the prevalence of "religion in the secular city" (to quote Harvey Cox's own response in this regard). ${ }^{8}$ There is certainly an amazing myriad of new religious movements, an interest in spirituality and transcendence and a revival of religious funda-

7. See the thorough discussion of some of these terms in Bosch (1991: 420-432).

8. See Cox (1984). 
mentalism all over the world. Indeed, the thesis that the global culture can be described as "secular" has been replaced with discourse on globalisation.

There is no need to revisit the multiple connotations of the process of secularisation here. It is important though to observe that one of the most basic challenges posed by secularisation has not yet been addressed satisfactorily by Christian theology. This is the challenge symbolised by the names of Copernicus and Darwin. Many Christian parents answer questions posed by their children such as "Who is God and where is God?" by vaguely pointing to the heavens above. Since Copernicus we know that God does not reside in the heavens above. It will not help to argue that God is "everywhere" either. Many theologians opt to emphasise the immanence of God (in Jesus Christ and through the Spirit). It is indeed helpful to say that we can best talk about God with reference to Jesus Christ. However, this does not clarify what it means to confess that this Jesus is indeed God.

The crucial question remains: How should the claim that God created the cosmos be understood in a post-Copernican world? Many Christian theologians have adopted theologies of creation that can no longer answer one of the crucial questions in life: Where does everything come from? These questions have become all the more important since the insights of astrophysics, geology, evolutionary biology (Darwin) and palaeontology have been integrated with one another in modern science to offer a single narrative of what Thomas Berry and others have called the "new creation story". 9 For many still secular people, informed by modern science, this story has simply replaced the Christian story that is no longer regarded as plausible.

The contemporary culture of globalisation is best understood as a continuation of the process of modernisation. The term globalisation is ambiguous and controversial and need not be discussed here. I only want to point out one paradox of a culture dominated by globalisation. One the one hand, globalisation is characterised by radical pluralism, conflicting diversity and cultural fragmentation. In a recent paper, Dirkie Smit persuasively argued that we do not live in time of unity. The dominant discourses of our day emphasise difference and otherness and are suspicious of language of unity and grand narratives. ${ }^{10} \mathrm{At}$ the same time, globalisation seems to suggest that the world in which we live has become one, a "global village" where everything is influenced by everything else. The problem with globalisation is that the forces that enforce such closeness remain elusive. They are clearly related to communication and information networks, the mass media, the regulation of trade, neo-liberal capitalism, the functioning of the market, the role of multi-national corporations, etc. These forces control our lives but are themselves difficult to locate probably because they have infiltrated every aspect of society, including our own assumptions, attitudes, expectations and habits. They seem to have spiralled beyond the control of political institutions or the structures of civil society. The pervasive power of the forces of globalisation calls for ideology-critical suspicion but also for theological critique. The question is whether the forces of globalisation have usurped the place of the divine. It is within this context that the World Alliance of Reformed Churches has initiated a "process of recognition, education, confession and action regarding economic injustice and ecological destruction". ${ }^{11}$

9. Berry and Swimme (1988).

10. Smit (2003).

11. Following its 23rd General Council in Debrecen, Hungary, in August 1997, the World Alliance of Reformed Churches published a study document with background papers reflecting on its call for a committed "process of recognition, education, confession and action regarding economic injustice and ecological destruction." 
At a more personal level the forces of globalisation are experienced and expressed in the now global culture of consumerism. This has created a new hegemony where, in the name of consumer choice and diversity, there is a proverbial Coca-Cola advertisement in every single village in the world. ${ }^{12}$ Moreover, as some would argue, the modernist critique against a radically transcendent God has not led to atheism but to the replacement of God by Mammon, the god of hedonism and consumerism.

\section{g) Religious Challenges}

The co-existence of different religious traditions within a culture of globalisation poses another important challenge to Christianity. The problem is not simply one of religious tolerance or an appreciation of religious diversity. This is certainly a real problem that is nowhere more evident than in the religiously-infused military conflicts that continue to wreak havoc in the world. The recent war in Iraq serves as a particularly ominous example in this regard. Indeed, as Hans Küng has often reiterated, there can be no peace in the world without peace between the world's religious traditions. And there can be no peace between religious traditions without dialogue between religious groups, especially on a common global ethos. ${ }^{13}$

Dialogue between religious traditions will only be possible if the truth claims of each tradition are taken seriously. Religion cannot be reduced to an aspect of culture, as some politicians would prefer it to be. The claim in Judaism, Christianity, Islam and most expressions of African Traditional Religion that God is the Creator of the whole cosmos surely suggests that everything else (including the state, politics and culture) is dependant on God and defined by its relationship with God. The problem of the co-existence of religious traditions is therefore the problem of conflicting truth claims. This is also the question addressed in Genesis 1: Who is the One who created heaven and earth: Elohim or Marduk?

This is clearly not the place to resolve debates on a theology of religions. I only wish to alert us to the widespread assumption, also prevalent among many Christians, that beyond the world's religious traditions there lurks a single, supreme divine being. According to this view, each of the various religious traditions expresses a particular understanding of this divine being. The truth claims of each tradition may therefore be appreciated. This view is usually described as religious pluralism (a misnomer since it assumes one God). It is perhaps typical of Hinduism: there is one mountain but there are many paths up the mountain. Not all paths allow one to get equally close to the top and none of them enables us to actually reach the top. The mystery of the divine being is protected in this way. If Thomas Berry is correct, this view of religion will become increasingly popular as the scientific reconstructions of the history of the universe become more widely known, as new religious movements spring up and as the influence of historical, institutionalised religions continue to wane. ${ }^{14}$

One may point out that this view is hardly compatible with the classic Christian doctrine of the trinity. The classic Christian conviction is that God is not different from, or hidden behind the One who is revealed to us in Jesus Christ and through the Holy Spirit. Christianity is not simply a particular instance of common religious experience either. The conflict between Christian truth claims and those of other religious traditions will have to

12. Colin Gunton (1993:13). See also my contributions on a culture of consumerism, (Conradie 2001, Conradie and Pauw 2002).

13. Küng (1991).

14. Berry (1999). 
be addressed. However, this does not nullify the cultural pervasiveness of this way of responding to religious plurality. The question is therefore how Christians will respond to this challenge. Indeed, how should Christians answer the question "Who is God and what is God doing in our world, today?".

\section{Various Ways of Responding to these Challenges}

How could or should Christianity in South Africa respond to these challenges? And how do Christians actually respond to these challenges? In the discussion below I will suggest 6 approaches that may be followed in this regard. The identification and description of these 6 approaches correlate with Ninian Smart's well-known analysis of 6 interrelated aspects or dimensions of religious traditions. Smart defines religion in the following way:

Religion is a six-dimensional organism, typically containing doctrines, myths, ethical teachings, rituals, and social institutions, and animated by religious experiences of various kinds. To understand the key ideas of religion, such as God and nirvana, one has to understand the pattern of religious life directed towards those goals. ${ }^{15}$

\section{a) Institutional Responses}

Ninian Smart notes that any religious tradition consists of people who are organised institutionally. The institution provides a social context where the identity of the particular religious tradition may be expressed. It also provides a certain stability for a religious tradition in order to ensure its continuation. Religious institutions therefore shape the social dimensions of religion. This is often the most visible manifestation of a religion. Christianity is, for example, often simply identified with "the church" because this is the most visible aspect of this particular religious tradition.

There needs to be a dynamic tension between the church as movement and institution. Many will argue that an emphasis on the church as institution will become rigid. It will turn the church into a museum. What is needed is religious experience that can activate people and function as catalyst to bring Christians to witness to Christ, to care for the helpless, to care for the environment, to transform the world. This leads to an emphasis on the church as movement. The experiential dimension of Christianity becomes important. However, such experiences will soon disappear and evaporate without the stabilising role of Christian institutions.

The history of Christianity is a never-ending story of the interplay between movement and institution, between the static and the dynamic. Whenever the church became fossilised in a rigid pattern, renewal movements emerged as protests against the established order. Whenever such renewal movements became too radical, the Christian tradition tended to lose its sense of continuity. To maintain a proper balance between institution and movement remains a challenge for the church.

It should be quite obvious that many Christians in South Africa respond to the challenges of our time by focusing their energies on institutional renewal. This applies, for example, to many impoverished congregations that have become completely bogged down in keeping the institution afloat - administratively and especially financially. This also applies to those who are entangled in church bureaucracy, whether at denominational level or in ecumenical structures. Where churches are faced with dwindling numbers due to secularisation, pastors are often engaged in a daily struggle to help the institution survive. Many others explore emerging forms of ecclesial management, leadership structures, cell

15. For a discussion of this definition, see Smart (1969: 15-25, 1973:42-43, 1983). 
groups, house churches, organised ministries, etc. This approach (the gospel of "gemeentebou") has been extremely popular amongst pastors in the Dutch Reformed Church over the last decade or two.

\section{b) Ethical Responses}

The ethical dimension of a religious tradition, Ninian Smart argues, is closely related to the institutional dimension. Institutions are not only "there", they also engage in various programmes and activities. These activities and programmes constitute, form and develop the ethos of the institution. At the same time, such an ethos is always situated within a particular social and therefore institutional context. We do not act purely as individuals. We act as mothers, fathers and children; as teachers and students, as members of a working team, as members of a congregation, as citizens of a town and a country, as residents of a community.

Many churches in South Africa have responded to the challenges of our time by focusing their energies on the social relevance of the Christian gospel. During the decades of struggle against apartheid, churches typically engaged in a prophetic mode of discourse to denounce the many evils that tormented South African society. More recently, many Christians have emphasised the need for a priestly engagement to respond to the needs of people who suffer as a result of poverty and employment, from HIV/AIDS, environmental injustice, domestic and gendered violence, various forms of social conflict, etc. African Christians have emphasised the need to attend to various problems related to social cohesion that are often ignored or neglected by mainline Christianity (e.g. healing, witchcraft, exorcism). Others simply continue to attend to the ongoing duty of the church to care for the sick, the elderly, the lonely, the deaf, the blind, the handicapped, and the poor.

An emphasis on the social relevance of the gospel can draw on a rich array of theological resources. These may include the resistance against oppression as articulated in liberation theology, black theology and feminist theology, Bonhoeffer's notion of the church for others, the emphasis on unity, reconciliation and justice expressed in the Belhar confession, a theology of mission (and development), Avery Dulles' description of the servant model of the church and many others. An emphasis on the social relevance of the gospel is an appropriate way of responding to secularisation too. However, as Avery Dulles also warns, an underlying danger of this approach is that the church may simply become another non-governmental organisation. Then it is no longer clear why the church is really necessary (expect for purely pragmatic reasons) to address such social challenges. Then language about God's action in the world becomes merely a way of talking about ecclesial praxis. The church has to do God's work in the world because it is no longer clear who God is, where God is and whether God's presence in our daily struggles makes any noticeable difference.

\section{c) Ritual Responses}

Ninian Smart notes that religious traditions tend to express themselves through worship, prayers and offerings. This constitutes the ritual dimension of a religious tradition. Rituals may be elaborate (e.g. the High Mass, a graduation ceremony) or simple (e.g. closing one's eyes in prayer). Rituals are usually identified by a sequence of actions performed in a particular order on a regular basis. Not all rituals are religious in nature. They may also be secular. Rituals form an integral part of personal and social relationships, e.g. greeting someone with "Good morning!". Other rituals include cultural customs like weddings, initiation ceremonies and funerals. 
The ritual dimension of religion has an outer and an inner aspect. The outer aspect is expressed in particular buildings, architecture, religious objects, clothing, body positions (e.g. kneeling), a set sequence of human behaviour, etc. If such outer patterns tend to dominate, rituals will degenerate into a mechanical procedure. If people go through the motions of religious observance without accompanying it with the intentions and sentiments that give it meaning, any ritual will soon become merely an empty shell. Such religious activities will then be condemned as ritualistic. This indicates a close relationship between ritual and the experiential dimension of religion. Christianity is often reduced to its ritualistic dimension. Nominal Christians often identify Christian living with some ritualistic elements, such as "going to church", "reading the Bible", "praying", "giving money to the church", etc. To be a Christian implies that one has to observe these rituals. This would indicate a ritualistic reduction of Christianity.

In terms of this analysis, one may argue that many churches in South Africa respond to the challenges that they are faced with through an innovation of their rituals, especially with respect to the style of worship. The need for Christianity with an African face is expressed especially within the context of Christian rituals. This includes the use of the vernacular in liturgy, African symbols (e.g. maize and beer instead of bread and wine), dance and music (using drums instead of organs), artistic expression, etc. Other churches are lured in the direction of Pentecostalism with its more expressive forms of worship. They explore any possible way of transforming a stagnated liturgy (e.g. by following the lead of Willow Creek). The rapid growth of African Pentecostalism suggests that the combination of these two approaches may be particularly attractive. Rituals may also be employed to resist change and to provide a sense of continuity and identity in a particular ecclesial tradition over an extended period of time. A retrieval of traditional rituals may also offer a way of responding to the threat of secularisation. Instead of a rational exposition of the cognitive content of the Christian faith, some secularised Christians find a sense of direction in retrieving and observing medieval Christian rituals and disciplines.

\section{d) Narrative Responses}

Religious traditions tend to grapple with the most fundamental assumptions and questions of human existence. These include questions about the origin and destiny of the world, about the forces of good and evil and about the task of human beings in society. Religious traditions typically address these "ultimate questions". They provide answers to these questions, especially in myth and ritual, through telling stories, in which something of the mystery of the universe and of life itself is conveyed. Ninian Smart calls this the mythic dimension of religion. The term "myth" does not imply a false account of history but an emphasis on story, on a sense of narrative identity.

Such a sense of narrative identity has traditionally been important in Christian communities. Christianity is indeed a historical religion for which the story of Abraham, Isaac and Jacob (and of Sarah / Hagar, Rebecca, Rachel / Lea) has become paradigmatic, if also ideologically problematic. Christians may understand their lives to be an extrapolation of the Biblical narratives. Indeed the Biblical story does not only form part of the Christian heritage. Christians live within the world of the Bible, that is, within the frame of reference portrayed by the Biblical narratives.

A retrieval of a sense of narrative identity is crucial for many Christians in South Africa. This is hardly surprising given the need to come to terms with the contested history and legacy of colonialism, Christian mission, slavery, apartheid, patriarchy, Afrikaner nationalism and the rise of African and also Coloured nationalism. This has become 
nowhere more obvious than in the narratives told during the hearings of the Truth and Reconciliation committee. More specifically, many African Christians have to clarify the relationship between their African past and the story of the emergence of Christianity in general and of each denomination in particular in (South) Africa.

It comes as no surprise that narrative approaches to theology (following George Lindbeck's lead), biblical hermeneutics (following the lead of Hans Frei and others) and ethics (following the leads of Alisdair MacIntyre and Stanley Hauerwas) have flourished in South Africa too. It should also be noted that an emphasis on narratives is also one way of responding to the challenge of secularisation. Those who have given up on the lofty propositional truth claims of Christianity may be content to tell a conflicting plurality of Christian stories and to live by the morals of such stories.

\section{e) Doctrinal Responses}

Ninian Smart describes the significance of doctrine in the following way: "Doctrines are an attempt to give system, clarity and intellectual power to what is revealed through the mythological and symbolic language of religious faith and ritual. ${ }^{, 16}$ Religious traditions are able to present a total picture of reality through a coherent system of doctrines. There is a close link between doctrine and all the other aspects of religious identity since doctrine is the result of a reflection on the cognitive content of religious identity as a whole.

There are several movements in the South African context that tend to underplay the importance of Christian doctrine. These include a resistance against modernist and intellectualist forms of Christianity, an emphasis on the need to reintegrate cognition, emotion and volition, an exploration of symbolic and non-verbal expressions of Christianity and postmodern suspicions against the self-assured truth claims for any particular religious tradition or denominational theology. Furthermore, the nature and function of Christian doctrine itself has been disputed. In his influential The Nature of doctrine, George Lindbeck, for example, identified three distinct ways of regarding doctrine, namely doctrine as propositional truths, doctrine as symbolic expressions of an underlying (universal) religious experience and doctrine as a description of the cultural and linguistic rules by which Christian communities live. ${ }^{17}$ Surprisingly, Lindbeck's preference for the culturallinguistic approach indicates that to describe the internal rules by which Christian communities live is the primary if not the only function of Christian doctrine. Theology in this mode has clearly become suspicious of any propositional truth claims.

Despite this widespread suspicion against the validity of the doctrines transmitted by the Christian tradition, there remains a lively interest in a clarification of Christian beliefs in a number of very different contexts in South Africa: a) The prevalence of numerous Bible schools in evangelical and Pentecostal Christianity in which Christian truth claims are affirmed and elucidated; b) The surprising (for some) interest in Biblical and Christian teaching amongst AIC's; c) The modernist questioning of Christian truth claims evident in the "New Reformation" that emerged amongst the intellectual elite in Afrikaans-speaking circles; d) The lively interest in recent dialogues between "Science and Religion" and between Christian theology and the sciences. The agenda of the latter two movements is governed by the challenges posed by secularisation, by the demand to know more about Biblical criticism (the Enlightenment critique against Christianity that has been withheld from many Christians by conservative pastors) and the need to reconcile the Christian story

16. Smart (1973:19).

17. Lindbeck (1984). 
with the story of the universe told by contemporary science. Interestingly, this has led to a new interest in the cognitive content and the propositional status of Christian truth claims. ${ }^{18}$

\section{f) Experiential Responses}

The experiential dimension of religion is both crucial and controversial. It is crucial because no religious tradition will be able to survive without ongoing religious experiences. Each new experience renews and sustains a particular tradition. It is controversial because religious experiences tend to be inward; they are not accessible for further scrutiny. To describe religious experience poses specific difficulties. We have to rely upon the testimony of the one who had the particular experience. Such a testimony has to be conveyed to us either by telling or writing. Such accounts of religious experiences may be preserved in oral tradition and in written texts. In this form, religious experiences are usually interpreted in terms of the prevailing doctrines and beliefs of the tradition. We cannot gain access to "pure" religious experiences. There is an inevitable interplay between religious experience and doctrine (or revelation).

An interest in Christian experience is especially evident in the widespread emphasis on spirituality, also in South Africa. The Christian tradition is characterised by a multiplicity of forms of spirituality. Some hear the voice of God through Christian preaching. For others the participation in the sacraments is crucial to experience God's presence. Others discover God's presence through music, e.g. through singing moving choruses or by re-enacting the gospel through rhythmic dancing. Yet others prefer the opportunity for contemplation and meditation that complete silence within a large cathedral allows. Some may be sensitive to the symbolism of sculptures, paintings, icons, architecture and other Christian works of art. Many experience something of God's presence through the fellowship (koinonia) and sharing of believers in small groups. Some may long for a more dramatic sign of God's presence, e.g. through speaking in tongues, healing, exorcism, charismatic leadership, etc. Many feel closer to God when they are alone in nature "out there", an environment preferably "uncontaminated" by human presence or interference.

\section{Religion cannot be Reduced to an Aspect of Culture}

Ninian Smart's analysis of the six aspects of dimensions of religion is certainly helpful to attend to the richness and complexity of any religious tradition. In this section I will nevertheless raise the question as to whether his analysis manages to do full justice to that which makes a religious tradition so typically religious. Does his analysis avoid reducing religion to an aspect of human culture?

In various earlier contributions I argued that religious traditions help societies to integrate their everyday experiences into a meaningful whole. ${ }^{19}$ Human communities construct for themselves a frame of reference, a social system of coordinates within which they can orientate themselves, socialise and communicate with others, educate their children and face the demands of life. The ongoing process of the social construction of reality (Berger) helps us to put things into a broader perspective, to understand new experiences within the context of a more comprehensive interpretation framework, to

18. Peacocke (2001:21) describes postmodernism as a "poisoned chalice" since it allows theology to be regarded as socially contextualised discourse applicable within religious communities but not to make any claims to relate to public realities. Theologians therefore retreat into spelling out the "grammar" of their received confessional traditions and are thereby self-exonerated from justifying their beliefs in the arena of public discourse.

19. See especially Conradie $(1995,2000)$. 
integrate our lives into a meaningful whole. Since we cannot observe the whole, any grasp of the whole has to be socially constructed. Integration is only possible through a unifying interpretation framework where a sense of unity is constructed (unum-facere) for the sake of simplicity.

The role and power of religion, I would argue, has to be understood within this context. Religious traditions provide an even more comprehensive sense of the whole by framing the whole of reality within the context of that which transcends reality, that is, of ultimate reality. ${ }^{20}$ For example, to understand the cosmos as being created by a God who transcends the cosmos radically redefines the way in which we view the cosmos and our place within the cosmos. One may follow David Tracy's lead here. Tracy argues that religions typically express a sense of the whole (and not only of a part) of reality:

And yet, in its own self-understanding, a religious perspective claims not to speak of a part but of the whole; without that reality of the whole, I believe, there is no 'religion'. There will be morality, art, science, politics, economics, each of which will locate a central part or dimension of our reality as personal, social, political and cultural human beings. A religious perspective, on the contrary, articulates some sense of the whole; it must inform, transform, at times even form the rest of our cultural lives with that sense or it loses its properly religious character. Then religion becomes, in fact, a synonym for morality, art, science or politics. ${ }^{21}$

And further:

A defining characteristic of an explicit religion ... is its "limit-of" or "ground-to" character, further specified as "some concrete manifestation of the whole by the power of the whole". 22

Peter Berger's analysis of the role of a symbolic universe within the social construction of reality also remains instructive here. Berger argues that the construction of a symbolic universe provides societies with such a sense of the whole: "...all the sectors of the institutional order are integrated in an all-embracing frame of reference, which now constitutes a universe in the literal sense of the word, because all human experience can now be conceived of as taking place within it." ${ }^{, 23}$ Religion plays a crucial role in this regard by locating the social construction of reality within a sacred and cosmic frame of reference and by bestowing on social institutions an ultimately valid ontological status. A symbolic universe provides the lenses through which new experiences are interpreted. It provides a social framework within which children are educated and new members are adopted and socialised. It re-describes the ethos of a community, the rules by which it lives.

In a pluralist society, Berger argues, various symbolic universes come to co-exist within the same geographical space. Then the absolute legitimacy of a particular religious definition of reality can no longer be maintained through extermination, segregation or incorporation. The de-monopolisation of a symbolic universe has far-reaching conesquences for its continued existence. Within a pluralist society social values are typically

20. See Pannenberg (1970:1). "The word 'God' is used meaningfully only if one means by it the power that determines everything that exists. Anyone who does not want to revert to a polytheistic or polydaemonistic stage of the phenomenology of religion must think of God as the creator of all things. It belongs to the task of theology to understand all being in relation to God, so that without God they simply could not be understood. This is what constitutes theology's universality."

21. Tracy (1981:159).

22. Tracy (1981:181).

23. Berger and Luckmann (1967:114). 
defined within distinct and semi-autonomous segments of society such as political governance, the economy, jurisprudence, health, education, arts and culture. The complexity of a pluralist society typically leads to a reduction of the sphere of influence of a symbolic universe to human sexuality, family life, self-actualisation, smaller communities and private life. Berger comments that "Such private religiosity, however 'real' it may be to the individuals who adopt it, can no longer fulfill the classical task of religion, that of constructing a common world within which all of social life receives ultimate meaning binding on everybody." ${ }^{24}$ A symbolic universe thus loses its all-inclusive scope and absolute validity because the whole is now constituted by a pluralist co-existence of various worldviews. This leads to the reduction of the status of a symbolic universe to that of a subuniverse. Berger suggests that: "Religion no longer legitimates 'the world'. Rather, different religious groups seek, by different means, their particular subworlds in the face of a plurality of subworlds." 25

Another way of describing the cosmic scope and the ultimate frame of reference, features, so characteristic of religious traditions, is with reference to religious cosmologies. Storytellers of all cultures seem to refuse to stop short of telling the cosmic story itself, however pretentious that may seem. ${ }^{26}$ With an astonishing sense of comprehensiveness, they tell stories about the cosmos as a whole. They provide us with a story of the origin and destiny of the universe and of the place of humanity within the cosmos. They answer the questions asked by children and adults alike: Who am I? Where do I come from? Where do I belong? What am I doing here? Why is life so hard and why must I suffer so much? Where does evil come? How can I be protected and saved from evil threats? What will happen to me when I die? What is the destiny of my life, my family, my people and this planet? Cosmological narratives provide a sense of belonging, a sanctuary, precisely because they dare to express the inexpressible: the whole of reality. Or, in the words of Thomas Berry:

For peoples, generally, their story of the universe and the human role in the universe is their primary source of intelligibility and value. Only through this story of how the universe came to be in the beginning and how it came to be as it is does, a person comes to appreciate the meaning of life or to derive the psychic energy needed to deal effectively with those crisis moments that occur in the life of the individual and in the life of the society. Such a story is the basis of ritual initiation throughout the world. It communicates the most sacred of mysteries... Our story not only interprets the past, it also guides and inspires our shaping the future. ${ }^{27}$

The classic task of religious cosmologies is to provide a sense of the whole and of where we fit into it, a frame of reference with ultimate explanatory power, absolute legitimacy, moral cohesion and cosmic scope. They explain why things are the way they are (cognitive) and also disclose how they should be (normative). They are therefore able to stir our emotions and to motivate our action. ${ }^{28}$ When cosmologies lose their grasp of the whole, this leads to a loss of a sense of identity with very serious moral consequences. Thomas Berry articulates this concern eloquently:

\footnotetext{
24. Berger (1967:133).

25. Berger (1967:152), italics - EMC.

26. Rasmussen (1994:176).

27. Berry (1988:xi).

28. See De Lange, also with reference to Berger's work.
} 
It's all a question of story. We are in trouble just now because we do not have a good story. We are in between stories. The old story, the account of how the world came to be and how we fit into it, is no longer effective. We have not yet learned the new story. Our traditional story of the universe sustained us for a long period of time. It shaped our emotional attitudes, provided us with life purposes, and energized action. It consecrated suffering and integrated knowledge. We awoke in the morning and knew where we were. We could answer the questions of our children. We could identify crime, punish transgressors. Everything was taken care of because the story was there... ${ }^{29}$

In a postmodern context it has become questionable whether new cosmological constructions of the "whole" are either desirable or possible. We have become hesitant to even attempt an articulation of the whole in the light of the historical, hermeneutical, linguistic, cultural, and gendered situatedness of all (!) discourse. We do not know everything and cannot grasp the whole in a single, unifying, totalising way. ${ }^{30}$ We also do not know that much about God or about the meaning of human existence - as Qoheleth and Job understood better than most. There is a widespread resistance against cosmological or theological meta-narratives. Following the societal critiques of Marx, Nietzsche, Freud, feminism and post-colonialism, the resistance against meta-narratives is at the same time born from an ethical rejection of the totalitarian nature of cosmologies. Cosmological reflection often serves as an ultimate justification for and sanctioning of a stable (if often oppressive) social order. Cosmological narratives can all too easily degenerate into royal propaganda. That Solomon's empire, Nazism and apartheid developed (and required) an elaborate cosmology should serve a timely warning here.

Nevertheless, it remains a question whether it possible for human societies to avoid a social construction of the whole. There is a danger of falling into the trap of what Wayne Booth calls "paradoxical umbrellas" ${ }^{31}$ According to Booth, a pluralist recognition of plurality has a tendency to become as absolutist as the monism that it rejects. There is a temptation to exclusivist truth claims with a different, pluralist view on the whole. In this way, pluralism may ironically become "the only way". Religious pluralism, for example, may be tempted to reject any exclusivist positions. Then only pluralist views on religious plurality are deemed acceptable. The theological worldviews of an age gone by may simply have been replaced by equally pervasive and homogenising secular worldviews - whether mechanical, materialist, Newtonian, positivist, scientist, capitalist, industrialist, nationalist, technocratic, or consumerist. The social fragmentation, unleashed by the Heraclitean flux, may well be balanced by the commercial homogeneity of a consumerist culture and a globalised economy that serves the capital interests of the rich and powerful. The danger of totalitarian rule or of religious fundamentalisms that rush to fill the social and political vacuum remains. It is indeed hardly surprising that religion continues to flourish in a socalled secularised world.

It seems to me that it is difficult to avoid social and religious constructions of the whole. The human brain tends to integrate a plurality of data into a single Gestalt. One of the functions of the concepts of space and time is to give a measure of unity to our experience of the world (Kant). They enable us to conceive of various categories as belonging together although they are distinct from one another. Despite the (legitimate) post-modern protests against closed systems, some form of comprehensive worldview or frame of reference may be unavoidable. Perhaps we also need an interpretative frame that is cosmic in scope. "We

29. Berry (1988:123).

30. See De Lange (1997:18).

31. Booth (1979:28f, 92f). 
are", Larry Rasmussen argues, "incorrigibly cosmic storytellers." 32 The problem with metaphysical meta-narratives is not that they are cosmic in scope but the underlying assumption that they offer a precise description of reality. ${ }^{33}$ It may therefore be more fruitful, and honest (!), not to deny one's own totalising strategies but to acknowledge them, to articulate them audaciously, and to expose them in this way to responses from the victims of these very strategies. In this way we need to remind ourselves that our own umbrellas (whether paradoxical or deliberate) will always harbour the danger of becoming totalising and totalitarian. This may help us in the search for less totalitarian constructions of the whole.

\section{The Christian Story: Some Broad Parameters}

The previous two sections may have created the impression that Christianity is a particular example of general form of religiosity. Some would indeed argue that an experience of transcendence, of divine presence, is prevalent among most if not all people. The one divine being has many names, many would say. Indeed, one may argue (as I did above) that questions about human identity that have a religious scope and significance are raised by all people. Nevertheless, it would be unwise to assume that there is indeed a common or universal religious experience underlying the wide diversity of religious traditions. There is actually no such thing as religion in general. We have to abstract from particular religious traditions to identify that which different religious traditions may have in common. And such abstractions may not always do justice to the particularity of any one religious tradition. In fact, religious traditions themselves are seldom homogenous. This does not imply that such abstractions may not prove valuable to tentatively formulate some common ground or to uncover that which is unique in religious experience.

Following these observations I will now offer some broad and preliminary parameters for a particularly Christian response to the challenges that were discussed above. An authentically Christian response should, I would think, retrieve the soteriological thrust of the Christian gospel as gospel, that is, as good news. It should not shy away from the heart of the Christian story, that is, with specific reference to the life, ministry, death and resurrection of Jesus Christ. It should not avoid language about God; it should articulate an honest response to the questions: "Who is God?" and "What is God doing in our world, today?"

The traditional Christian answer to the question as to who God is, suggests that God has been and is being disclosed to us as Father, Son and Holy Spirit. In the renaissance of trinitarian theology over the last two decades, following the earlier lead of especially Karl Barth, this answer has gained a new impetus. Although I have reservations about the innertrinitarian mysticism that the new interest in the community of love within the (immanent) trinity seems to elicit, the emphasis on the story of the triune God's love for the world (the so-called economic trinity) seems to me entirely appropriate. The task of Christian theology may perhaps be described as re-telling, retrieving and re-interpreting the integral story of God's creative, nourishing, hurt, enduring, salvific, innovating and consummating love for that which God has brought to life.

To formulate the task of Christian theology in this way suggests the need to integrate (but not to confuse or to conflate) that which has become separated for too long: God and the world; creation and redemption; body and soul; reality and morality; matter, ideas and

32. Rasmussen (1994:178).

33. De Lange (1997:19). 
language; emotion, cognition and volition; animal and human; female and male; incarnation and ascension; cross and resurrection; creation and eschaton. The narrative of God's love for the world will lose its plausibility whenever it is allowed to disintegrate in any of these ways. This problem may be illustrated with reference to the inability of recent Christian theologies to do justice to both the themes of creation and redemption.

- Since the days of Copernicus, Newton and later Darwin, Christian theology and Christian piety have struggled to explain how the world can be plausibly viewed as God's creation. As I have noted above, when our children ask us "Where is God?", many of us still point vaguely to the heavens above even though we know quite well that God is not somewhere up in the blue sky.

- In response to the cosmological problem posed by modern science, Protestant and especially evangelical theology followed a route described by Moltmann as a "retreat from cosmology into personal faith" ${ }^{34}$ Christian piety responded by desperately trying to heal the broken relationship between humanity and an increasingly transcendent God. However, this theology of personal redemption could not be plausible as long as the relation between God and the world remained obscure. The problem that had to be addressed was not only personal or societal but indeed cosmic in scope.

- Dialectical theology, following the lead of Von Rad and Barth, resolved this problem by regarding the faith of Israel in a Creator God as an extrapolation of its faith in the Saviour of Israel. They argued that the noetic priority lay with Israel's experiences of God's redemption in history. The theme of creation itself, understood as God establishing some order amidst the chaos (following the destruction of Jerusalem), was reinterpreted to include a soteriological thrust. Creation, Oepke Noordmans argued, is not forming or making; it is a critical concept, judging all our prevailing ideas about what is natural. It is only in the crucified Christ that we discover who the Creator God is. ${ }^{35}$

- Contemporary theological movements such as liberation theology, black theology, feminist and womanist theology maintained the emphasis on redemption but understood it in societal instead of personalist terms, i.e. as liberation from oppression and victory over the many contemporary manifestations of evil. However, this does not resolve the problem of understanding how the liberating praxis of the poor, oppressed and marginalised could be interpreted as God's own action in the world. In fact, one may wonder whether theological language about God is more than just a way of providing impetus to the social agenda of the church in its struggle for "Justice, Peace and the Integrity of Creation."

- In some ecological theologies, especially in the form of the creation spirituality proposed by Matthew Fox and Thomas Berry, the theological pendulum has swung to the extreme opposite, namely to an almost exclusive interest in the theme of creation. The Western pre-occupation with sin and redemption is criticised in order to retrieve a sense of the sacredness of God's "original blessing", 36

- This renewed theological interest in the theme of creation is especially evident in recent dialogues between Christian theology and the natural sciences. During the last decade or two considerable theological energies have been devoted to relate the Christian doctrines of creation, providence and humanity to the insights emerging from astro-

34. Moltmann (1985:34). See my discussion (Conradie 1997) of the impact of this retreat from cosmology into personal faith in the South African context.

35. Noordmans (1934:63-65).

36. See the title of Fox's influential work (1983). 
physics, evolutionary biology, the cognitive sciences and paleontology. It is interesting to note that the classic Christian message about sin and redemption receives comparatively little interest in such dialogues - except in the form of the theodicy problem of explaining the emergence of natural forms of suffering and evil and in attempts to offer a generalised account of how divine action in the world may be understood. The same tendency may also be identified in theological schools such as process theology.

- The need to relate the themes of creation and redemption is recognised, interestingly enough, in a very different form in indigenous theologies, especially in African theology. This is born from the African quest for identity. What is the continuity between a pre-Christian African notion of the creator God and the Christian message of redemption that took root in Africa following the work of Western missionaries? Mercy Amba Oduyoye, for example asks: "Is the God of our redemption the same God of our creation?"37

These rather wide-ranging comments suggest that a far more thorough theological integration of the themes of creation and redemption is required. Such an integration is perhaps only possible if creation, providence, fall, redemption and eschatological consummation is understood not as separate and successive events (as was traditionally the case) but as three ongoing features of the single narrative of God's love for creation. ${ }^{38}$ Moreover, the relationship between the Christian story and the story of the universe as told by contemporary science calls for urgent clarification. This task of theological integration cannot be addressed here for obvious reasons. ${ }^{39}$

In this theological task of telling the integrated Christian story of God's love for the world, the soteriological thrust of the gospel has to be maintained. This can only be done adequately if the rich array of soteriological themes that are employed in the Christian tradition is taken into account. These include (in random order) liberation in cases of political oppression, victory in cases of severe military threats, rescue in cases of violent attacks, healing in cases of sickness, nourishment amidst food scarcity and famine, protection from danger and threats to one's life and dignity, the establishment of political order in cases of virtual anarchy, wisdom amidst foolishness and a loss of indigenous knowledge, exorcism in cases where evil forces threaten, debt cancellation in cases of crippling debt, restoration in cases of (economic) injustices, reconciliation in cases of family or labour disputes, peace in cases of violent conflict, fellowship in cases of loneliness, rootlessness or alienation, forgiveness in cases of inter-personal or inter-community wrongdoing, reparation in cases of environmental devastation, etc.

The Christian tradition has tended to conflate these soteriological themes through the use of categories such as "salvation", "redemption" and "forgiveness" of sins. It is probably fair to say that the Christian gospel promises a sense of comprehensive well-being (Klaus Nürnberger) that can address all these human predicaments. At the same time, some structural differences between these soteriological themes should be recognised. The gospel addresses the evil consequences of human sin (e.g. God's victory over evil, based on the message of resurrection), the roots of such evil in human sin (e.g. our sins are forgiven by God through grace, based on the cross of Jesus Christ) and a way to live in the present in

37. Oduyoye (2000:75)

38. See Barbour (2002:50).

39. In my view, the oeuvres of Colin Gunton, Jürgen Moltmann and Arnold van Ruler, perhaps together with those of Douglas John Hall, Paul Santmire and Joseph Sittler offer the most promising sense of direction for this task. I envisage a future research project that will investigate the relationship between creation and redemption from the perspective of ecological theology. 
order to ensure a sustainable future (epitomised in the incarnation, life and ministry of Jesus of Nazareth who demonstrated the full intent of God's law).

\section{Conclusion}

These comments do not yet offer an adequate answer to theological questions such as "Who is God?" and "What is God doing in the world today?" It should be clear that God transcends all our modest or not so modest theological attempts to answer such questions. God is not in our control. If anything, we are in God's hands and have to live our lives in God's presence. We can be nothing more than witnesses to the self-disclosure of God.

These comments may, however, offer some broad parameters within which contemporary Christian witnesses to God's love can be tested. Any contemporary Christian witnesses to God's love, any form of Christian spirituality, one may argue, has to a) address the challenges of our time, b) attend to the variety of ways in which Christians can respond to such challenges, c) avoid a reductionist response, and d) ensure that such a response do justice to the full Christian story of God's love for the world.

\section{BIBLIOGRAPHY}

Barbour, IG 2002. Nature, human nature, and God. Minneapolis: Fortress Press.

Bellah, R et al. Habits of the heart. San Francisco: Harper and Row.

Berger, PL and Luckmann, T 1967. The social construction of reality: A treatise in die sociology of knowledge. New York: Penguin Press.

Berger, PL 1967. The sacred canopy: elements of a sociological theory of religion. New York: Doubleday.

Berry, T 1988. The dream of the earth. San Francisco: Sierra Club Books.

Berry, T 1999. The great work: Our way into the future. New York: Bell Tower.

Booth, WC 1979. Critical understanding: The powers and limits of pluralism, Chicago: The University of Chicago Press.

Bosch, DJ 1991. Transforming mission: Paradigm shifts in theology of mission. Maryknoll: Orbis Books.

Conradie, EM and Jonker, LC 2001. Angling for interpretation. A guide to understand the Bible better. Study Guides in Religion and Theology 4. Bellville: University of the Western Cape.

Conradie, EM and Pauw, JC 2002. Dialogiese, ekologiese en teologiese perspektiewe ten opsigte van 'n verbruikerskultuur ("consumerism"). Ned Geref Teologiese Tydskrif 43:3and4, 407-422.

Conradie, EM 1993. Teologie as 'n kritiese refleksie oor die kerklike praxis. Tydskrif vir Geesteswetenskappe 33:3, 196-207.

Conradie, EM 1990. Modelle van teologie as handeling. Scriptura S6.

Conradie, EM 1995. Waar op dees aarde kan 'n mens nog 'n enigste troos in lewe en in sterwe vind? Ned Geref Teologiese Tydskrif 35:2, 224-250.

Conradie, EM 1997. Reconstructing an ecological cosmology: A South African contribution. Scriptura 61, 213-230.

Conradie, EM 2000. Hope for the earth - Vistas on a new century. Bellville: University of the Western Cape. 
Conradie, EM 2001. On cosmology, plurality and morality. Ned Geref Teologiese Tydskrif 42:3-4, 278-286.

Cox, H 1984. Religion in the secular city. Toward a postmodern theology. New York: Simon and Schuster.

Daneel, ML 1987. Quest for belonging. Introduction to the study of African Independent Churches. Gweru: Mambo Press.

De Lange, F 1997. Gevoel voor verhoudingen: God, evolutie, ethiek. Kampen: Kok.

Fox, M 1983. Original blessing. Santa Fe: Bear and Co.

Gunton, C 1993. The One, the Three and the Many: God, creation and the culture of modernity. Cambridge: Cambridge University Press.

Küng, H 1991. Global responsibility: In search of a new world ethic. New York, NY: Crossroad.

Lindbeck, GA 1984. The nature of doctrine: Religion and theology in a post-liberal age. Philadelphia: Westminster Press.

Moltmann, J 1985. God in creation. London: SCM Press.

Noordmans, O 1934. Herschepping. Utrecht: J Van Boekhoven.

Oduyoye, Mercy Amba 2000. Hearing and knowing: Theological reflections on Christianity in Africa. Nairobi: Acton Publishers.

Pannenberg, W 1970. Basic questions in theology.

Peacocke, AR 2001. Paths from science to God: The end of all our exploring. Oxford: Oneworld Publications.

Rasmussen, LL 1993. Moral fragments and moral community. Philadelphia: Fortress Press.

Rasmussen, LL 1994. Cosmology and ethics. In: Tucker, ME and Grimm, JA (eds.): Worldviews and ecology. Religion, philosophy, and the environment, 173-180. Maryknoll: Orbis Books.

Rasmussen, LL 1996. Earth community, earth ethics. Maryknoll: Orbis Books.

Smart, N 1969. The religious experience of mankind. New York: Collins.

Smart, N 1973. The phenomenon of religion. London: Mowbrays.

Smart, N 1983. Worldviews: Crosscultural explorations of human beliefs. New York: Charles Scribner's Sons.

Smit, DJ 2003. Unity in church and society? - Theological reflections on an ongoing challenge in South Africa today. Paper read at a symposium on "present challenges for the Dutch Reformed Church, Stellenbosch in a changing South Africa, 14 March 2003.

Swimme, B and Berry, T 1992. The universe story. From the primordial flashing forth to the ecozoic era. New York: Penguin Books.

Tracy, DW 1981. The analogical imagination: Christian theology and the culture of pluralism. London: SCM Press.

Wellman, DH 2001. Sustainable communities. Geneva: World Council of Churches

White, L 1967. The historical roots of our ecological crisis. Science 155, 1203-7.

Wuthnow, R 1993. Christianity in the twenty-first century. Reflections on the challenges ahead. Oxford: Oxford University Press. 